\section{Kidney \\ Blood Pressure Research}

Kidney Blood Press Res 2012;36:172-181

\begin{tabular}{l|l}
\hline DOI: $10.1159 / 000343406$ & (c) 2012 S. Karger AG, Basel
\end{tabular}

Published online: October 30, 2012

www.karger.com $/ \mathrm{kbr}$

172

Original Paper

\title{
Comparison of the Diagnostic Performance of Three Natriuretic Peptides in Hemodialysis Patients: Which is the Appropriate Biomarker?
}

\author{
Ferruh Artunc $^{\mathrm{a}} \quad$ Christian Mueller $^{\mathrm{b}} \quad$ Tobias Breidthardt $^{\mathrm{b}} \quad$ Raphael Twerenbold ${ }^{\mathrm{b}}$ \\ Ingo Rettig ${ }^{a}$ Engin Ustac Hans-Ulrich Häring ${ }^{a}$ Björn Friedrich ${ }^{a, d}$ \\ aDepartment of Internal Medicine, Division of Endocrinology, Diabetology, Vascular Disease, \\ Nephrology and Clinical Chemistry, University of Tübingen, Germany, ${ }^{b}$ Department of Internal \\ Medicine, Division of Cardiology, University of Basel, Switzerland, 'Department of Vascular Surgery, \\ University of Tübingen, Germany, dDialysis Center, Leonberg, Germany
}

\section{Key Words}

Natriuretic peptides $\cdot$ Hemodialysis $•$ Mortality

\begin{abstract}
Background: Plasma concentrations of natriuretic peptides are often elevated in chronic hemodialysis patients and difficult to interpret due to accumulation, high incidence of cardiac disease and changes in volume status. Mid-regional pro-ANP is a newly developed assay whereas BNP and its fragment NT-pro-BNP are available for a longer time. In this cross-sectional study, we compared the plasma concentration of MR-pro-ANP, BNP and NT-pro-BNP in stable ambulatory hemodialysis patients $(n=239)$ and investigated their associations with clinical factors such as residual diuresis, cardiac status and interdialytic weight gain and with mortality. Methods and Results: In all patients enrolled, the plasma concentration of all natriuretic peptides were largely elevated with a median concentration of $337 \mathrm{pg} / \mathrm{ml}$ (interquartile range 146-684) for BNP, $4435 \mathrm{pg} / \mathrm{ml}$ (1687-16228) for NT-proBNP and $907 \mathrm{pmol} / \mathrm{L}$ (650-1298) for MR-pro-ANP. Plasma concentration of all natriuretic peptides correlated independently with age, degree of systolic dysfunction and negatively with residual diuresis. Dependency on residual renal clearance was strongest for the fragments MR-pro-ANP and NT-pro-BNP. The plasma concentration of all natriuretic peptides was associated with mortality within 2 years of follow-up. Receiver-operated curves revealed a low sensitivity (32-45\%), but high specificity for all natriuretic peptides (85-93\%) resulting in a high negative predictive (82-87\%). Best cut-off values obtained from were $18611 \mathrm{pg} / \mathrm{ml}$ for NT-pro-BNP, $958 \mathrm{pg} / \mathrm{ml}$ for BNP and $1684 \mathrm{pmol} / \mathrm{L}$ for MR-pro-ANP. Conclusions: In hemodialysis patients, the fragments NTproBNP and MR-pro-ANP are largely elevated compared to BNP which is explained by accumulation. The prognostic performance of MR-pro-ANP is similar to that of NT-proBNP or BNP.

Copyright $@ 2012$ S. Karger AG, Basel

Ferruh Artunc, MD

Department of Internal Medicine, Division of Endocrinology, Diabetology,

Angiology and Nephrology, University Hospital of Tuebingen, Otfried-Mueller-Str. 10

72076 Tuebingen (Germany), Tel. +49 7071 2982711, Fax +49 7071 293174,

E-Mail ferruh.artunc@med.uni-tuebingen.de
\end{abstract}




\section{Kidney Blood Pressure Research}

Kidney Blood Press Res 2012;36:172-181

\begin{tabular}{l|l}
\hline DOI: $10.1159 / 000343406$ & (c) 2012 S. Karger AG, Basel \\
\hline
\end{tabular}

Published online: October 30, 2012

www.karger.com/kbr

Artunc/Mueller/Breidthardt et al.: Natriuretic Peptides and Hemodialysis

\section{Introduction}

Elevations of the plasma concentration of natriuretic peptides are commonly found in chronic hemodialysis patients and are associated with increased mortality [1-5]. Physiologically, natriuretic peptides such as atrial and B-type natriuretic peptide (ANP and BNP) are secreted from cardiac muscle in response to an elevated filling pressure and reflect volume overload [6, 7]. In patients with heart failure, this response is highly stimulated and results in sometimes largely elevated plasma levels which can be utilized for diagnostic purposes $[8,9]$. After secretion of precursor peptides, biologically active ANP and BNP is formed after cleavage of $\mathrm{N}$ - and C-terminal fragments leaving peptides of 28 and 32 amino acids in length and 3 and $3.5 \mathrm{kDa}$ in weight, respectively. The clearance of ANP and BNP is achieved by the serum protease neutral endopeptidase and after receptor binding [6]. The most common markers measured in clinical practice are BNP and the N-terminal fragment of pro-BNP (NT-pro-BNP) whereas the determination of ANP is hampered by its instability ex vivo [10]. Therefore, assays measuring the concentration of stable precursor pro-ANP were developed $[11,12]$. In 2004, a novel assay detecting mid-regional pro-ANP (MR-pro-ANP) was developed [13]. Up to the present, only one study evaluated its value in hemodialysis patients showing an association with mortality [14]. In predialysis patients, MR-pro-ANP was predictive of progression of renal failure [15].

In patients with end-stage renal disease, largely elevated plasma natriuretic peptide concentrations are difficult to interpret due to possibly reduced renal clearance and accumulation on the one hand and a high prevalence of cardiac disease and heart failure, even in the in the presence of preserved ejection fraction, on the other $[16,17]$. In addition, plasma natriuretic peptide concentrations are affected by the volume status [18], which varies particularly between the hemodialysis sessions. Still, plasma natriuretic peptide concentrations have proven to be a strong predictor of mortality in ESRD patients $[4,19]$.

In our study, we analyzed factors influencing the plasma concentration of MR-pro-ANP, BNP and NT-pro-BNP in a comparative approach in stable ambulatory hemodialysis patients in order to investigate the contribution of accumulation, cardiac disease or volume status. In addition we analyzed the prognostic value of each natriuretic peptide.

\section{Materials and Methods}

\section{Patients and cohort}

This cross-sectional prospective multicentre study was conducted in stable ambulatory hemodialysis patients from four dialysis centers in Southwest Germany between September 2009 and April 2010. Patients were included after obtaining informed consent, when there was no evidence of an acute illness such as infection and a cardiac event such as myocardial infarction or percutaneous coronary procedure within the previous two months. Patients with cardiac diseases leading to increased plasma natriuretic peptide concentration independent of ESRD such as amyloidosis were excluded. The study was approved by the local ethics committee.

\section{Laboratory assays}

Plasma concentration of MR-pro-ANP, NT-pro-BNP and BNP was measured in three independent samples taken within 2 weeks, each prior to the start of a dialysis session. Blood was collected in lithiumheparinized tubes (Fa. Sarstedt, Nuembrecht, Germany), cooled at $4^{\circ} \mathrm{C}$, centrifuged within 4 hours and the sera stored at $-80^{\circ} \mathrm{C}$ for further analysis. Plasma concentration of MR-pro-ANP was measured using an automated immunoluminometric assay on a Kryptor system (B.R.A.H.M.S AG, Henningsdorf, Germany) as described in [13]. In healthy persons, the range of MR-pro-ANP concentrations was 9.6-313 pmol/L with a median of $45 \mathrm{pmol} / \mathrm{L}$ and a 99th percentile of $197.5 \mathrm{pmol} / \mathrm{L}$ [13]. Plasma concentration of BNP and NT-proBNP were measured on a Siemens ADVIA Centaur and Siemens Immulite 2000 XPi system, respectively, as specified by the manufacturer (Siemens Healthcare Diagnostics, Eschborn, Germany). 


\section{Kidney \\ Blood Pressure Research}

Kidney Blood Press Res 2012;36:172-181

\begin{tabular}{l|l}
\hline DOI: $10.1159 / 000343406$ & (c) 2012 S. Karger AG, Basel
\end{tabular}

Published online: October 30, 2012

www.karger.com/kbr

Artunc/Mueller/Breidthardt et al.: Natriuretic Peptides and Hemodialysis

Plasma beta-2-microglobulin concentration was measured using a turbidimetric assay (Randox Laboratories, Antrim, United Kingdom). All other laboratory values (parathormone, hemoglobin, albumin and C-reactive protein) were extracted from the patients' medical records and averaged from the available values of the previous year ( $4-12$ values).

Clinical data

From each patient data on residual diuresis (measured by $24 \mathrm{~h}$ urine collection), single pool Kt/V (mean of last 4 values), interdialytic weight gain, predialytic systolic and diastolic blood pressure (means from the last 12 values, resp.), dialysis access and membrane, time on dialysis, blood pump flow and finally shunt flow (measured with a Transonic system, Ithaca, NY, USA) were extracted. Left ventricular (LV) systolic function was classified from available echocardiography examinations whereby class 1 denoted normal, 2 mildly reduced, 3 moderately or severely reduced systolic function. Determination of the LV systolic function was done at the discretion of the cardiologist and not standardized. Echocardiography was available in $84 \%$ of all patients within one year (plus-minus) relative to study enrollment.

\section{Statistical analysis}

Three samples were available in $87 \%$ of the patients and were averaged to calculate the arithmetic mean without excluding possible outliers. Arithmetic means of the plasma natriuretic peptide concentration and continuous clinical data were log transformed to approximate normal distribution. The association of the plasma natriuretic peptide concentration with clinical or dialysis-related factors was analyzed by univariate parametric correlation. To identify independent determinants of the plasma natriuretic peptide concentration, multivariate linear regression analyses were performed. Selection of the variables entering the model were derived from forward-stepwise multiple linear regression, and all variables with a p-value $<0.05$ were subsequently included in the multivariate linear regression models. Finally, the residuals of each model were tested for normality. Averaged values of the deceased patients were compared to those from the surviving patients using t-Test or Wilcoxon's test. Kaplan-Meier curves were generated after stratification into tertiles of the variable according to its distribution. The follow-up period started on the first day of blood draw and was censored as of January 2012. The diagnostic performance was analyzed using receiver-operater curves (ROC or c-index) and the best cut-off value was considered as the maximal difference of sensitivity and 1-specificity (Youden index). Univariate and multivariate proportional hazards were calculated to analyze the risk ratios of each predictor and the independence of the predictors. Data analysis was done using the statistical software package JMP 8.0.1 (SAS Institute, Cary, NC).

\section{Results}

\section{Patients}

From a total of $n=250$ available patients treated in the participating centers, $n=239$ were included in the study. $\mathrm{N}=11$ patients were excluded due to decline to participate $(\mathrm{n}=$ $6)$, death within the period of blood sampling $(n=2)$, cardiac amyloidosis $(n=2)$ and recent enrollment to dialysis $(n=1)$. The characteristics of the study cohort are given in table 1 .

\section{Plasma natriuretic peptide concentration in the cohort}

In all participating patients, the plasma concentration of MR-pro-ANP was elevated with a median concentration of $907 \mathrm{pmol} / \mathrm{L}$ (650-1298) and exceeded the upper limit used to diagnose heart failure at $130 \mathrm{pmol} / \mathrm{L}$ [20] (Figure 1A). This proportion was $99 \%$ for NT-pro-BNP $>300 \mathrm{pg} / \mathrm{mL}$ [21] and $81 \%$ for BNP $>100 \mathrm{pg} / \mathrm{mL}$ [9]. Plasma natriuretic peptide concentrations were highly correlated to each other, with the highest correlation between MR-pro-ANP and BNP (0.86, $\mathrm{p}<0.0001)$, followed by BNP and NT-pro-BNP $(0.51$, $\mathrm{p}<0.0001)$ and MR-pro-ANP and NT-pro-BNP $(0.47, \mathrm{p}<0.0001)$. Within three samples, the variability was least for MR-pro-ANP (10 $\pm 9 \%)$, followed by NT-pro-BNP (23 $\pm 16 \%)$ and BNP $(32 \pm 21 \%)$. The plasma concentration of MR-pro-ANP was significantly higher after an interdialytic interval of 3 days than of 2 days $(1027$ [702; 1370] vs. 802 [536; 1232] pmol/l). 


\section{Kidney \\ Blood Pressure Research}

Table 1

\begin{tabular}{|c|c|c|}
\hline \multicolumn{2}{|c|}{ Patient characteristics of the cohort $(n=239)$} & \multirow{2}{*}{$\begin{array}{l}\begin{array}{l}\text { Values shown are the median and } \\
\text { interquartile range }\end{array} \\
70(61 ; 77) \text { years }(n=239)\end{array}$} \\
\hline median age & & \\
\hline gender distribution & & $64 \%$ male $(n=153) / 36 \%$ female $(n=86)$ \\
\hline \multirow[t]{5}{*}{ renal disease } & diabetic nephropathy & $26 \%(n=63)$ \\
\hline & hypertension & $8 \%(n=19)$ \\
\hline & glomerulonephritis & $30 \%(n=71)$ \\
\hline & polycystic disease & $5 \%(n=11)$ \\
\hline & other / unknown & $31 \%(n=75)$ \\
\hline \multirow[t]{6}{*}{ cardiac comorbidities } & coronary heart disease & $31 \%(n=74)$ \\
\hline & revascularized & $19 \%(n=31)$ \\
\hline & valvular heart disease & $26 \%(n=61)$ \\
\hline & atrial fibrillation & $23 \%(n=55)$ \\
\hline & pulmonary hypertension & $7 \%(n=16)$ \\
\hline & AICD carrier & $2 \%(n=4)$ \\
\hline \multirow[t]{6}{*}{ other comorbidities } & diabetes mellitus & $38 \%(\mathrm{n}=90)$ \\
\hline & peripheral vascular disease & $33 \%(n=80)$ \\
\hline & stroke & $16 \%(n=38)$ \\
\hline & vasculitis & $3 \%(n=8)$ \\
\hline & malignoma & $14 \%(n=34)$ \\
\hline & COPD & $8 \%(n=19)$ \\
\hline length of time on dialysis & & $46(19 ; 85)$ months $(n=239)$ \\
\hline duration of dialysis session & & $4.0(4.0 ; 4.5)$ hours $(n=239)$ \\
\hline \multirow[t]{3}{*}{ dialysis access } & arteriovenous fistula & $71 \%(n=169)$ \\
\hline & PTFE graft & $13 \%(n=31)$ \\
\hline & tunneled catheter & $16 \%(n=38)$ \\
\hline \multirow[t]{2}{*}{ dialysis membrane } & high-flux & $92 \%(n=219)$ \\
\hline & low-flux & $8 \%(n=20)$ \\
\hline \multirow[t]{2}{*}{ residual diuresis } & & $250(0 ; 1000) \mathrm{ml} /$ day $(\mathrm{n}=239)$ \\
\hline & anuric patients & $39 \%(n=93)$ \\
\hline interdialytic weight gain & & $1.85(1.29 ; 2.47) \operatorname{kg}(n=239)$ \\
\hline blood pump speed & & $300(280 ; 340) \mathrm{ml} / \min (\mathrm{n}=239)$ \\
\hline shunt flow & & $1080(733 ; 1475) \mathrm{ml} / \min (\mathrm{n}=187)$ \\
\hline blood pressure & & $134(122 ; 144) / 69(63 ; 74) \mathrm{mm} \mathrm{Hg}(\mathrm{n}=239)$ \\
\hline pulse pressure & & $65(54 ; 74) \mathrm{mm} \mathrm{Hg}(\mathrm{n}=239)$ \\
\hline singe pool Kt / V & & $1.55(1.40 ; 1.73)(n=239)$ \\
\hline \multirow[t]{5}{*}{ laboratory data } & hemoglobin & $11.5(11.1 ; 12.0) \mathrm{g} / \mathrm{dl}(\mathrm{n}=239)$ \\
\hline & C-reactive protein & $8.6(4.6 ; 15.0) \mathrm{mg} / \mathrm{l}(\mathrm{n}=239)$ \\
\hline & albumin & $37.1(35.4 ; 39.3) \mathrm{g} / \mathrm{l}(\mathrm{n}=239)$ \\
\hline & parathormone & $204(130 ; 348) \mathrm{pg} / \mathrm{ml}(\mathrm{n}=239)$ \\
\hline & $\beta 2$-microglobulin & $23.4(19.4 ; 25.4) \mathrm{mg} / \mathrm{l}(\mathrm{n}=239)$ \\
\hline \multirow[t]{4}{*}{ LV systolic function } & normal & $59 \%(n=140)$ \\
\hline & mildly reduced & $13 \%(n=32)$ \\
\hline & moderately or severely reduced & $12 \%(n=29)$ \\
\hline & unknown & $16 \%(n=38)$ \\
\hline
\end{tabular}

The same was true for BNP (435 [186; 888] vs. 274 [86; 532] pg/ml) and NT-pro-BNP (5407 [2044; 19401] vs. 2355 [1115; 8229] pg/ml).

\section{Univariate analyses}

Table 2 lists the results of univariate correlation analyses of the plasma natriuretic peptide concentration with the collected parameters. MR-pro-ANP as well as BNP and NTpro-BNP showed a significant positive correlation to age, degree of systolic dysfunction, time on dialysis and blood pump speed and they were all negatively correlated to residual diuresis. MR-pro-ANP and NT-pro-BNP were further positively correlated to interdialytic weight gain and plasma $\beta 2$-microglobulin concentration. 


\section{Kidney \\ Blood Pressure Research}

Table 2: Univariate correlations (Pearson's r) of the plasma natriuretic peptide concentration with general and dialysis-specific parameters $(n=210-239)$

\begin{tabular}{|c|c|c|c|}
\hline & $\begin{array}{c}\text { MR-pro- } \\
\text { ANP, pmol/L }\end{array}$ & NT-pro-BNP, pg/ml & $\mathrm{BNP}, \mathrm{pg} / \mathrm{m}$ \\
\hline age, $y$ & $0.25^{* *}$ & $0.20^{* *}$ & $0.32^{* * *}$ \\
\hline systolic LVF, classes & $0.40^{* * *}$ & $0.26 * *$ & $0.46^{* * *}$ \\
\hline time on dialysis, months & $0.25^{* *}$ & $0.12 \#$ & $0.13 *$ \\
\hline residual diuresis, $\mathrm{ml} /$ day & $-0.26 * * *$ & $-0.17^{* *}$ & $-0.16 *$ \\
\hline interdialytic weight gain, $\mathrm{kg}$ & $0.17^{* *}$ & 0.11 \# & n.s. \\
\hline shunt flow, $\mathrm{ml} / \mathrm{min}$ & n.s. & n.s. & n.s. \\
\hline systolic blood pressure, mm Hg & n.s. & n.s. & n.s. \\
\hline diastolic blood pressure, $\mathrm{mm} \mathrm{Hg}$ & n.s. & n.s. & n.s. \\
\hline pulse pressure, $\mathrm{mm} \mathrm{Hg}$ & n.s. & n.s. & 0.11 \# \\
\hline duration of a HD session & n.s. & n.s. & n.s. \\
\hline blood pump speed, $\mathrm{ml} / \mathrm{min}$ & $0.13 \#$ & $0.14 \#$ & 0.12 \# \\
\hline $\mathrm{Kt} / \mathrm{V}$ & n.s. & n.s. & n.s. \\
\hline hemoglobin, g/dL & n.s. & n.s. & n.s. \\
\hline plasma albumin, $\mathrm{g} / \mathrm{L}$ & n.s. & n.s. & n.s. \\
\hline C-reactive protein, mg/L & $0.21 * *$ & n.s. & $0.17 * *$ \\
\hline parathormone, $\mathrm{pg} / \mathrm{mL}$ & 0.11 \# & n.s. & $0.15 *$ \\
\hline$\beta 2$-microglobulin, $\mathrm{mg} / \mathrm{dL}$ & $0.32 * * *$ & $0.27 * * *$ & n.s \\
\hline
\end{tabular}
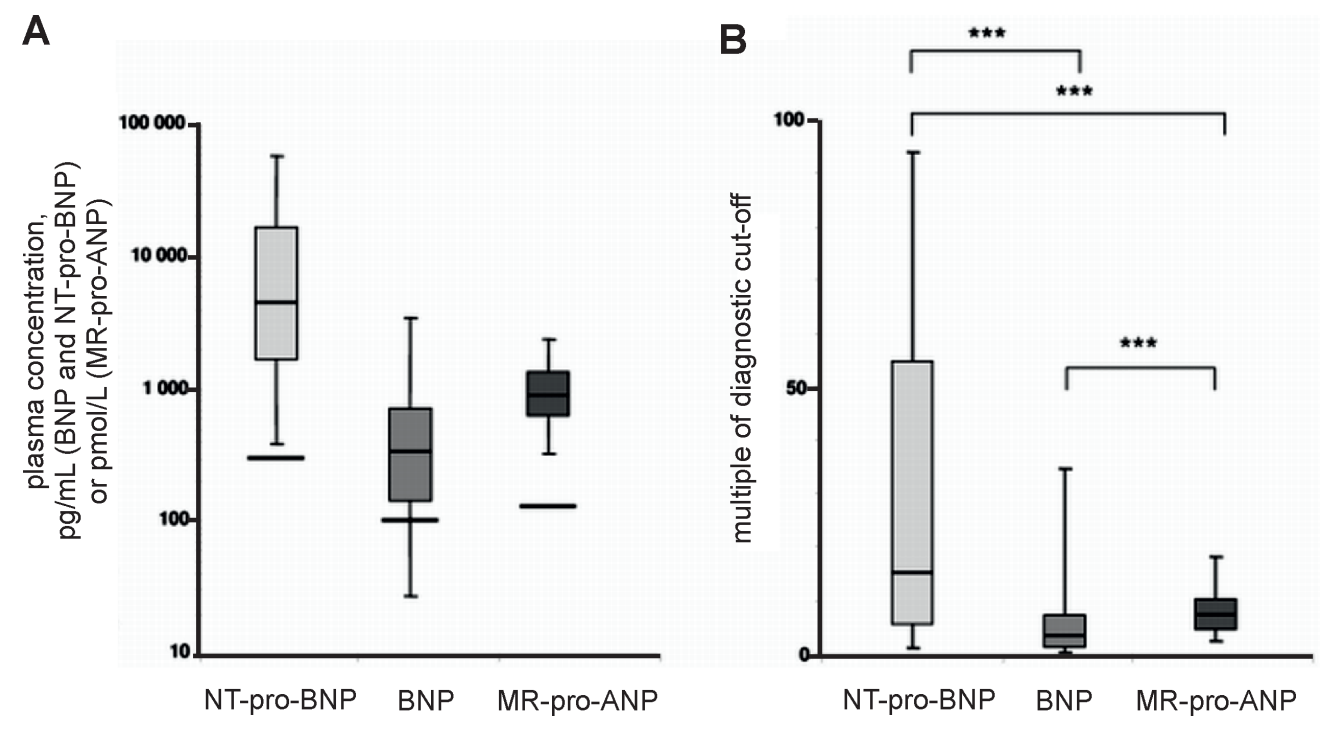

Fig. 1. A: Box-and-Whiskers-Plot of the plasma natriuretic peptide concentration indicating median, interquartile range and the range between the $2.5^{\text {th }}$ and $97.5^{\text {th }}$ percentile. Solid lines represent the upper reference limit used to diagnose heart failure $(<100 \mathrm{pg} / \mathrm{mL}$ for BNP [9], $300 \mathrm{pg} / \mathrm{mL}$ for NT-pro-BNP [21], 130 pmol/L for MR-pro-ANP [20]). B: Box-and-Whiskers-Plot of the plasma natriuretic peptide concentration expressed as multiples of the cut-off used for diagnosing heart failure, respectively. ${ }^{* *}$ indicates significant difference $(p<0.0001)$ between the natriuretic peptide concentration.

\section{Multivariate analyses}

To analyze independent determinants of the MR-pro-ANP plasma concentrations, a multivariate linear regression model was performed with a stepwise forward approach. Table 3 lists independent determinants with a p-value of $<0.05$ and their contribution to the 


\section{Kidney \\ Blood Pressure Research}

Table 3: Independent factors determining plasma natriuretic peptide concentration by stepwise multivariate linear modelling $(n=155$ - 201)

\begin{tabular}{llccc}
\hline & covariate & estimate \pm SD & $\begin{array}{c}\text { standardized } \\
\text { estimate } \pm \text { SD }\end{array}$ & p-value \\
\hline MR-pro-ANP & y-intercept & $-0.06 \pm 0.65$ & & \\
& age, y & $0.68 \pm 0.14$ & $0.19 \pm 0.04$ & $<0.0001$ \\
& systolic LVF, classes [3 vs. 2] & $0.15 \pm 0.05$ & $0.15 \pm 0.05$ & 0.0050 \\
& diastolic blood pressure, mm Hg & $0.80 \pm 0.27$ & $0.13 \pm 0.04$ & 0.0040 \\
& residual diuresis, ml/24 h & $-8 \cdot 10^{-5} \pm 2 \cdot 10^{-5}$ & $-0.11 \pm 0.02$ & $<0.0001$ \\
& systolic LVF, classes [2 vs. 1] & $0.10 \pm 0.04$ & $0.10 \pm 0.03$ & 0.0115 \\
NT-pro-BNP & $0.11 \pm 0.05$ & $0.07 \pm 0.03$ & 0.0380 \\
& shunt flow, ml/min & $0.36 \pm 0.92$ & & \\
& y-intercept & $1.37 \pm 0.38$ & $0.37 \pm 0.10$ & 0.0005 \\
& age, y & $0.36 \pm 0.12$ & $0.36 \pm 0.12$ & 0.0030 \\
& systolic LVF, classes [2 vs. 1] & $-8 \cdot 10^{-4} \pm 5 \cdot 10^{-5}$ & $-0.31 \pm 0.07$ & $<0.0001$ \\
& residual diuresis, ml/24 h & $0.30 \pm 0.16$ & $0.30 \pm 0.16$ & 0.0594 \\
& systolic LVF, classes [3 vs. 2] & $0.28 \pm 0.16$ & $0.18 \pm 0.10$ & 0.0838 \\
& shunt flow, ml/min & $-2.07 \pm 1.37$ & & \\
& y-intercept & $0.29 \pm 0.09$ & $0.29 \pm 0.09$ & 0.0016 \\
& systolic LVF, classes [3 vs. 2] & $0.40 \pm 0.12$ & $0.30 \pm 0.11$ & 0.0124 \\
& systolic LVF, classes [2 vs. 1] & $-1 \cdot 10^{-4} \pm 4 \cdot 10^{-5}$ & $-0.18 \pm 0.06$ & 0.0065 \\
& residual diuresis, ml/24 h & $1.44 \pm 0.33$ & $0.47 \pm 0.11$ & $<0.0001$ \\
& age, y & $1.04 \pm 0.59$ & $0.21 \pm 0.12$ & 0.0762 \\
\hline
\end{tabular}
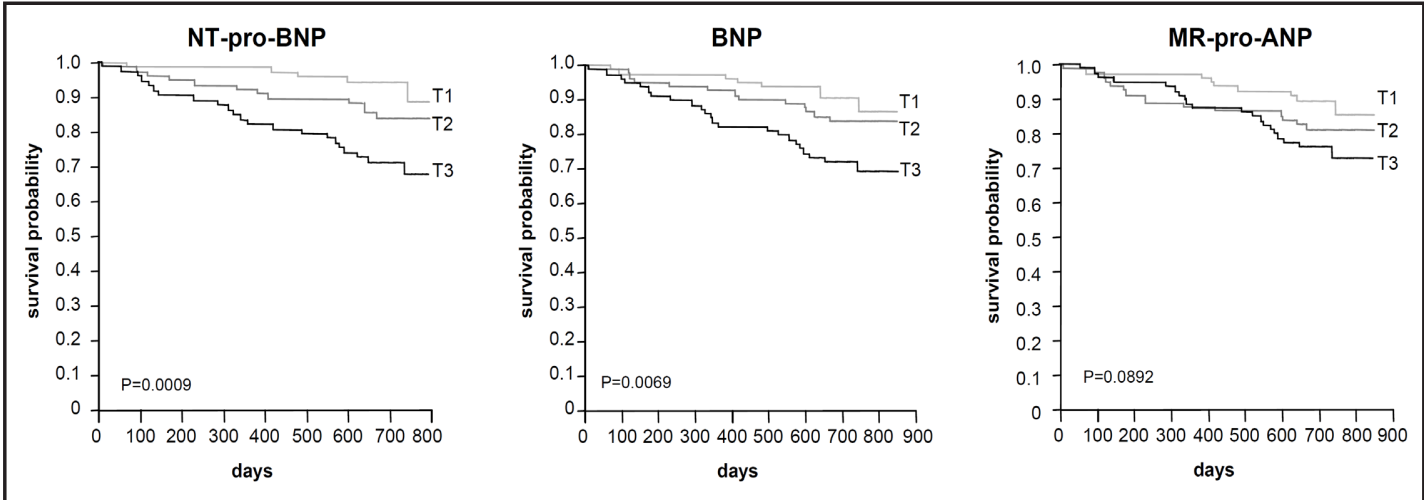

Fig. 2. Survival curves of the cohort stratified according to tertiles (T1, T2 and T3) of MR-pro-ANP $(<724$; 724 - 1159; > 1159 pmol/l), NT-pro-BNP $(<2384 ; 2384$ - 8412; > 8412 pg/ml) and BNP $(<195 ; 195$ - 528 ; $>528 \mathrm{pg} / \mathrm{ml}$ ) plasma concentration.

model indicated by the standardized estimate. Independent determinants of the MR-proANP, NT-pro-BNP and BNP plasma concentration were age, systolic LV function and residual diuresis. Diastolic blood pressure and shunt flow were also determinants of MR-pro-ANP. MR-pro-ANP had the highest $r^{2}$ with 0.4185 indicating that $42 \%$ of the variability in plasma MR-pro-ANP concentration could be explained by these factors (Table 3). In contrast, the best model found for BNP and NT-pro-BNP had an $\mathrm{r}^{2}$ of 0.3283 and 0.3190 respectively.

\section{Prognostic value}

During a median follow-up time of 710 days $(679 ; 761), 44$ patients died corresponding to an annual mortality rate of $9.46 \%$. Compared to surviving patients, deceased patients were 


\section{Kidney Blood Pressure Research}

Table 4: Prognostic performance of the plasma natriuretic peptide concentration in predicting death during follow-up

\begin{tabular}{llcccccc}
\hline & cut-off & $\begin{array}{c}\text { AUC (c- } \\
\text { index) }\end{array}$ & $\begin{array}{c}\text { Youden } \\
\text { index }\end{array}$ & $\begin{array}{c}\text { sensitivity, } \\
\%\end{array}$ & $\begin{array}{c}\text { specificity, } \\
\text { \% }\end{array}$ & $\begin{array}{c}\text { positive } \\
\text { predictive } \\
\text { value, \% }\end{array}$ & $\begin{array}{c}\text { negative } \\
\text { predictive } \\
\text { value, \% }\end{array}$ \\
\hline MR-pro-ANP & $1684 \mathrm{pmol} / \mathrm{l}$ & 0.62 & 0.25 & 32 & 93 & 50 & 86 \\
NT-pro-BNP & $18611 \mathrm{pg} / \mathrm{ml}$ & 0.64 & 0.27 & 43 & 84 & 13 & 82 \\
BNP & $958 \mathrm{pg} / \mathrm{ml}$ & 0.66 & 0.31 & 45 & 85 & 41 & 87 \\
\hline
\end{tabular}

Fig. 3. Hazard ratio for mortality according to tertiles (T1, T2 and T3) of MR-pro-ANP (< 724; 724 - 1159; $>1159 \mathrm{pmol} / \mathrm{l})$, NTpro-BNP (< 2384; 2384 - 8412; > 8412 $\mathrm{pg} / \mathrm{ml}$ ) and BNP (< 195; 195 - 528; $>528 \mathrm{pg} / \mathrm{ml}$ ) plasma concentration. The hazard ratio of the first tertile was set to $1 .^{*} \mathrm{p}<0.05$, ${ }^{* *} \mathrm{p}<0.01$.

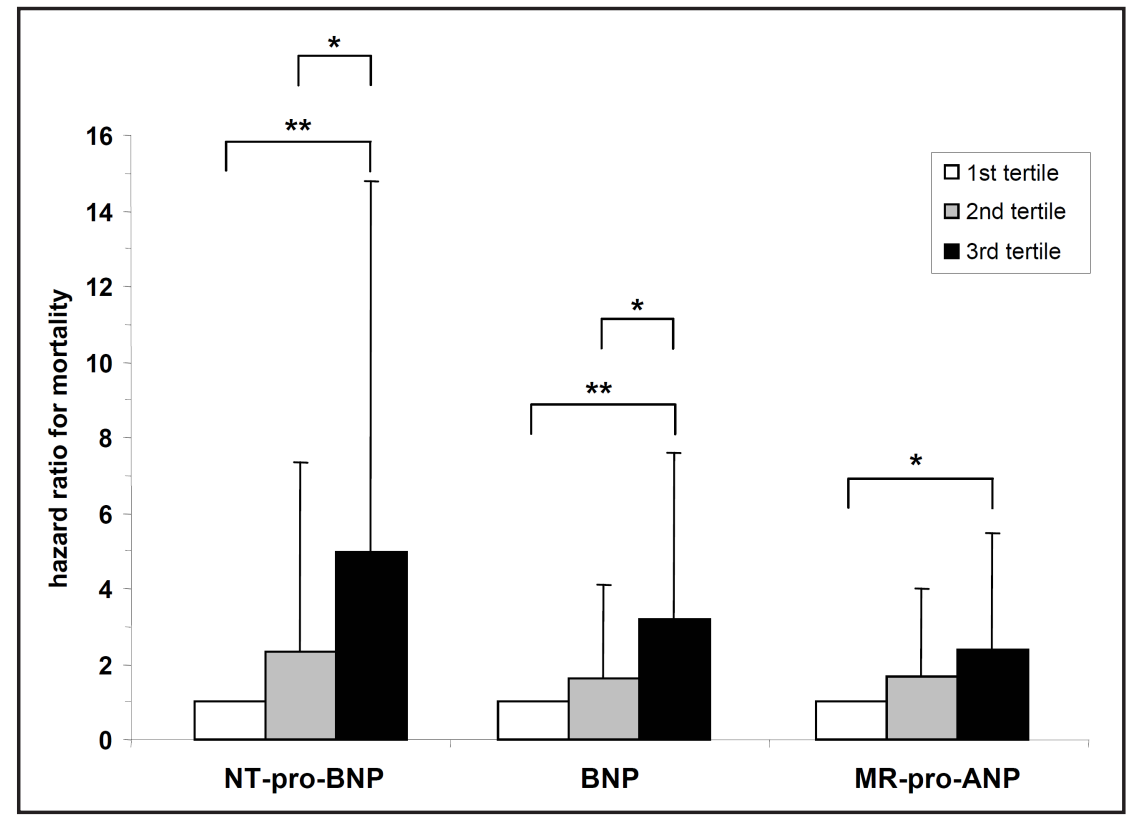

significantly older (77 years [68;82] vs. 69 [59; 76]; $<<0.0001$ ), were more likely to have LV dysfunction ( $68 \%$ vs. $24 \%$; p $<0.0001$ ) and had lower diastolic blood pressure (65 $\mathrm{mm} \mathrm{Hg} \mathrm{[59}$ ;72] vs. 69 [63; 74]; $p=0.0087)$. The concentration of MR-pro-ANP was significantly $(p<0.01)$ higher in deceased patients compared to surviving patients 1106 [746;1806] pmol/L vs. 865 [634;1235] pmol/L, which was similar for NT-pro-BNP 12993 [4360; 29416] pg/mL vs. 3760 [1485; 11571] and BNP 577 [257;1772] pg/mL vs. 299 [127;573] pg/mL.

The survival curves stratified for tertiles of plasma natriuretic peptide concentrations are shown in Figure 2, the relative risk compared to the first tertile is shown in Figure 3. When analyzing the diagnostic performance of plasma natriuretic peptides concentrations using contingency tables and receiver-operator curves (Table 4), all natriuretic peptides showed similar AUC-values and had a high negative predictive value (82 - 87\%). For each increase of the plasma natriuretic peptide concentration by $100 \mathrm{pmol} / \mathrm{L}$ for MR-pro-ANP, by $100 \mathrm{pg} / \mathrm{mL}$ for BNP and $1000 \mathrm{pg} / \mathrm{mL}$ for NT-pro-BNP, the risk ratio was increased by $7.8 \%$, $6.1 \%$ and $2.4 \%$, respectively. In a multivariate proportional hazards model with age, systolic function and plasma natriuretic peptides concentration, plasma BNP and NT-pro-BNP concentration, but not plasma MR-pro-ANP concentration, were independent predictors $(p<0.05)$ of mortality in addition to systolic function (data not shown). 


\section{Kidney Blood Pressure Research}

Kidney Blood Press Res 2012;36:172-181

\begin{tabular}{l|l}
\hline DOI: $10.1159 / 000343406$ & $\begin{array}{l}\text { C } 2012 \text { S. Karger AG, Basel } \\
\text { www.karger.com/kbr }\end{array}$ \\
Published online: October 30, 2012 &
\end{tabular}

Published online: October 30, 2012

Artunc/Mueller/Breidthardt et al.: Natriuretic Peptides and Hemodialysis

\section{Discussion}

This study demonstrates that MR-pro-ANP has a similar performance in stable hemodialysis patients compared to BNP and NT-pro-BNP. Our data show that the MR-pro-ANP plasma concentrations were to a much greater extent dependent on residual renal clearance compared to BNP and resulted in concentrations above the upper limit used to diagnose heart failure in all patients. This finding was also evident for NT-pro-BNP plasma concentrations suggesting that the clearance of these fragments is highly dependent on residual function in contrast to BNP which can be eliminated after binding to the natriuretic peptide clearance receptor and the action of neutral endopeptidase $[22,23]$. The accumulation of the plasma natriuretic peptide concentration limits its clinical use in patients with chronic kidney disease. Müller et al. found that determination of BNP in dyspnoeic patients presenting to an emergency department improved patient management only little as opposed to patients without renal disease due to increased baseline concentrations of BNP which decreases the negative predictive value to rule out cardiac failure [24]. In our study, the negative predictive value for the end point mortality was still high with values $>80 \%$ indicating a good prognosis in patients with a plasma natriuretic peptide concentration below the calculated cutoff values (Table 4). However, the sensitivity and positive predictive values were low and preclude accurate prediction in an individual patient.

The diagnostic value of plasma natriuretic peptide concentration in hemodialysis patients can be improved by establishing specific cut-off values for this population. McCullough et al. found that a BNP plasma concentration of $>225 \mathrm{pg} / \mathrm{ml}$ should be applied when a patient has a GFR $<30 \mathrm{ml} / \mathrm{min} / 1,73 \mathrm{~m}^{2}$ [25]. For MR-pro-ANP, the cut-off for diagnosing heart failure was found to be $130 \mathrm{pmol} / \mathrm{L}$ in the BACH (Biomarkers in Acute Heart Failure) trial [20]. However, a cut-off value adapted to patients with CKD and, even hemodialysis, has not been established. Our data show, that there is substantial retention of MR-pro-ANP in hemodialysis patients resulting in MR-pro-ANP plasma concentrations greater than this threshold in all patients included in this study.

In the study of Gouya et al. a MR-pro-ANP plasma concentration in the upper tertile (greater than $795 \mathrm{pmol} / \mathrm{l}$ ) was associated with a 1.76-fold increased mortality risk in 201 hemodialysis patients during a follow-up of seven years $(p=0.08)$ [14]. In our study, we found a significant $(\mathrm{p}<0.01) 2.4$-fold increase in mortality in patients with a MR-pro-ANP plasma concentration in the upper tertile (greater than $1159 \mathrm{pmol} / \mathrm{l}$ ) and a 1.7 fold increase in mortality in patients in the middle tertile (MR-pro-ANP plasma concentration between 724 and 1159) which did not reach statistical significance $(\mathrm{p}=0.20)$. More studies are needed to better define cut-off values of the MR-pro-ANP plasma concentration for diagnostic and prognostic purposes.

The dependence of the plasma concentration of MR-pro-ANP and NT-pro-BNP on residual diuresis and kidney function in addition to heart function makes these fragments useful markers of the cardio-renal syndrome since elevated plasma concentrations reflect both increased cardiac secretion and reduced residual renal function which is an independent predictor of mortality in hemodialysis patients [26]. This could be the reason for the high range of the observed NT-pro-BNP plasma concentration with a 800 -fold difference between the lowest and the highest value (Figure 1) which translated to a higher relative mortality risk of the upper tertile compared to that of BNP (4.95-fold vs. 3.17-fold; Figure 3). However, the fragment MR-pro-ANP (98 amino acids) had the smallest range with only a 17-fold difference between the lowest and the highest value (Figure 1). The reason for this remains unclear but could involve differences of the secretion compared to ventricle-derived BNP. Accordingly, the mortality risk of the upper tertile of MR-pro-ANP was the lowest (2.36-fold; Figure 3).

The limited number of cardiac parameters that were collected might have contributed to an unexplained variability during multivariate modeling. Survival analyses might be limited by the low mortality during the follow-up period. This study focused on nephrological parameters that are commonly available and accessible during hemodialysis treatment, such 


\section{Kidney \\ Blood Pressure Research}

Artunc/Mueller/Breidthardt et al.: Natriuretic Peptides and Hemodialysis

as residual diuresis or shunt flow. Systolic left ventricular function served as a surrogate for cardiac status and still showed a high correlation to the plasma natriuretic peptide concentration. Other cardiac morbidities, such as diastolic function [16], valvular disease or rhythm disturbances, might also contribute to elevations in natriuretic peptide concentration, but were not entered into the model. Again it should be emphasized that association studies cannot prove causality between the studied parameters and elevated plasma natriuretic peptide concentrations and cannot distinguish between cause and consequence.

In hemodialysis patients, the fragment MR-pro-ANP is largely elevated due to accumulation. The prognostic performance of MR-pro-ANP is not superior to that of NT-proBNP or BNP.

\section{Conflict of Interest}

none

\section{Acknowledgements}

We thank Andrea Janessa and Claudia Stelzig for their valuable assistance during the study, we also thank Ken Newill, BSc, for his help during the preparation of the manuscript.

\section{References}

1 Madsen LH, Ladefoged S, Corell P, Schou M, Hildebrandt PR, Atar D: N-terminal pro brain natriuretic peptide predicts mortality in patients with end-stage renal disease in hemodialysis. Kidney Int 2007;71:548-554.

-2 Sun L, Sun Y, Zhao X, Xu C, Chen D, Li L, Ma Y, Rong S, Mei C: Predictive role of BNP and NT-proBNP in hemodialysis patients. Nephron Clin Pract 2008;110:c178-c184.

- 3 Goto T, Takase H, Toriyama T, Sugiura T, Kurita Y, Tsuru N, Masuda H, Hayashi K, Ueda R, Dohi Y: Increased circulating levels of natriuretic peptides predict future cardiac event in patients with chronic hemodialysis. Nephron 2002;92:610-615.

4 Wang AY, Lai KN: Use of cardiac biomarkers in end-stage renal disease. J Am Soc Nephrol 2008;19:16431652.

5 Spinar J, Ludka O, Dusek L, Vitovcova L, Sobotova D, Spinarova L, Tomandl J, Vitovec J: Neurohumoral activity, heart failure and prognosis in patients with end-stage renal disease treated by hemodialysis. Kidney Blood Press Res 2007;30:347-357.

-6 de Lemos JA, McGuire DK, Drazner MH: B-type natriuretic peptide in cardiovascular disease. Lancet 2003;362:316-322.

-7 Tsutamoto T, Wada A, Sakai H, Ishikawa C, Tanaka T, Hayashi M, Fujii M, Yamamoto T, Dohke T, Ohnishi M, Takashima H, Kinoshita M, Horie M: Relationship between renal function and plasma brain natriuretic peptide in patients with heart failure. J Am Coll Cardiol 2006;47:582-586.

8 Maisel AS, Krishnaswamy P, Nowak RM, McCord J, Hollander JE, Duc P, Omland T, Storrow AB, Abraham WT, Wu AH, Clopton P, Steg PG, Westheim A, Knudsen CW, Perez A, Kazanegra R, Herrmann HC, McCullough PA: Rapid measurement of B-type natriuretic peptide in the emergency diagnosis of heart failure. N Engl J Med 2002;347:161-167.

-9 Mueller C, Scholer A, Laule-Kilian K, Martina B, Schindler C, Buser P, Pfisterer M, Perruchoud AP: Use of B-type natriuretic peptide in the evaluation and management of acute dyspnea. N Engl J Med 2004;350:647-654.

10 Buckley MG, Marcus NJ, Yacoub MH: Cardiac peptide stability, aprotinin and room temperature: importance for assessing cardiac function in clinical practice. Clin Sci (Lond) 1999;97:689-695. 


\section{Kidney \\ Blood Pressure Research}

Kidney Blood Press Res 2012;36:172-181

\begin{tabular}{l|l}
\hline DOI: $10.1159 / 000343406$ & C 2012 S. Karger AG, Basel
\end{tabular}

Published online: October 30, 2012

www.karger.com $/ \mathrm{kbr}$

Artunc/Mueller/Breidthardt et al.: Natriuretic Peptides and Hemodialysis

-11 Numata Y, Dohi K, Furukawa A, Kikuoka S, Asada H, Fukunaga T, Taniguchi Y, Sasakura K, Tsuji T, Inouye K, Yoshimura M, Itoh H, Mukoyama M, Yasue H, Nakao K: Immunoradiometric assay for the N-terminal fragment of proatrial natriuretic peptide in human plasma. Clin Chem 1998;44:1008-1013.

-12 Missbichler A, Hawa G, Schmal N, Woloszczuk W: Sandwich ELISA for proANP 1-98 facilitates investigation of left ventricular dysfunction. Eur J Med Res 2001;6:105-111.

13 Morgenthaler NG, Struck J, Thomas B, Bergmann A: Immunoluminometric assay for the midregion of proatrial natriuretic peptide in human plasma. Clin Chem 2004;50:234-236.

-14 Gouya G, Sturm G, Lamina C, Zitt E, Freistatter O, Struck J, Wolzt M, Knoll F, Lins F, Lhotta K, Neyer U, Kronenberg F: The association of mid-regional pro-adrenomedullin and mid-regional pro-atrial natriuretic peptide with mortality in an incident dialysis cohort. PLoS One 2011;6:e17803.

15 Dieplinger B, Mueller T, Kollerits B, Struck J, Ritz E, von EA, Haltmayer M, Kronenberg F: Pro-A-type natriuretic peptide and pro-adrenomedullin predict progression of chronic kidney disease: the MMKD Study. Kidney Int 2009;75:408-414.

-16 Kamano C, Osawa H, Hashimoto K, Nishimura S, Saito SK, Kashiwagi T, Iino Y, Katayama Y: N-Terminal ProBrain Natriuretic Peptide as a Predictor of Heart Failure with Preserved Ejection Fraction in Hemodialysis Patients without Fluid Overload. Blood Purif 2011;33:37-43.

17 McCullough PA, Sandberg KR: B-type natriuretic peptide and renal disease. Heart Fail Rev 2003;8:355-358.

18 David S, Kumpers P, Seidler V, Biertz F, Haller H, Fliser D: Diagnostic value of N-terminal pro-B-type natriuretic peptide (NT-proBNP) for left ventricular dysfunction in patients with chronic kidney disease stage 5 on haemodialysis. Nephrol Dial Transplant 2008;23:1370-1377.

19 Nakatani T, Naganuma T, Masuda C, Sugimura T, Uchida J, Takemoto Y, Sugimura K: The prognostic role of atrial natriuretic peptides in hemodialysis patients. Blood Purif 2003;21:395-400.

-20 Maisel A, Mueller C, Nowak R, Peacock WF, Landsberg JW, Ponikowski P, Mockel M, Hogan C, Wu AH, Richards M, Clopton P, Filippatos GS, Di SS, Anand I, Ng L, Daniels LB, Neath SX, Christenson R, Potocki M, McCord J, Terracciano G, Kremastinos D, Hartmann O, von HS, Bergmann A, Morgenthaler NG, Anker SD: Mid-region pro-hormone markers for diagnosis and prognosis in acute dyspnea: results from the BACH (Biomarkers in Acute Heart Failure) trial. J Am Coll Cardiol 2010;55:2062-2076.

-21 Januzzi JL, Jr., Camargo CA, Anwaruddin S, Baggish AL, Chen AA, Krauser DG, Tung R, Cameron R, Nagurney JT, Chae CU, Lloyd-Jones DM, Brown DF, Foran-Melanson S, Sluss PM, Lee-Lewandrowski E, Lewandrowski KB: The N-terminal Pro-BNP investigation of dyspnea in the emergency department (PRIDE) study. Am J Cardiol 2005;95:948-954.

22 Wegner M, Ganten D, Stasch JP: Neutral endopeptidase inhibition potentiates the effects of natriuretic peptides in renin transgenic rats. Hypertens Res 1996;19:229-238.

-23 Ozaki J, Shimizu H, Hashimoto Y, Itoh H, Nakao K, Inui K: Enzymatic inactivation of major circulating forms of atrial and brain natriuretic peptides. Eur J Pharmacol 1999;370:307-312.

-24 Mueller C, Laule-Kilian K, Scholer A, Nusbaumer C, Zeller T, Staub D, Perruchoud AP: B-type natriuretic peptide for acute dyspnea in patients with kidney disease: insights from a randomized comparison. Kidney Int 2005;67:278-284.

25 McCullough PA, Duc P, Omland T, McCord J, Nowak RM, Hollander JE, Herrmann HC, Steg PG, Westheim A, Knudsen CW, Storrow AB, Abraham WT, Lamba S, Wu AH, Perez A, Clopton P, Krishnaswamy P, Kazanegra $\mathrm{R}$, Maisel AS: B-type natriuretic peptide and renal function in the diagnosis of heart failure: an analysis from the Breathing Not Properly Multinational Study. Am J Kidney Dis 2003;41:571-579.

26 van der Wal WM, Noordzij M, Dekker FW, Boeschoten EW, Krediet RT, Korevaar JC, Geskus RB: Full loss of residual renal function causes higher mortality in dialysis patients; findings from a marginal structural model. Nephrol Dial Transplant 2011;26:2978-2983. 